\title{
British Diplomacy on Demonstrations of March and April 1981 in Yugoslavia (Kosovo)
}

Fati Iseni

$\mathrm{PhD}$, Associate Prof. Dr. of Political History, State University "Mother Teresa”, Skopje, Republic of North Macedonia

Agim Jakupi

PhD Cand. Ass. Professor of Political History, State University "Mother Teresa”, Skopje, Republic of North Macedonia

\section{Abstract}

Great Britain since the late 19th and early 20th centuries had increased its interest for the developments in the Balkan region. Since the Berlin Congress in June 1878, the Conference of Ambassadors in London, December 1912-May 1913, then during WWI and WWII. Her interest continued also during the Cold War. Tito's Yugoslavia as a conglomerate of peoples had special diplomatic treatment from UK because of political, economic and military interests of the latter. Mostly after 1948 the UK built good relations with Yugoslavia. Her interest was Yugoslavia to remain stable as it was the west "protected" area from any Soviet Union threat. From this perspective the predictions were that the British could approve of any kind of internal behavior towards other ethnic minority communities. Thus in 1981 riots broke out in the province of Kosovo, Yugoslavia, and they escalated widely all over Kosovo. The UK closely followed all developments through its embassy in Belgrade and reported continuously to the FCO in London. This research will be exclusively based on these Telegrams. The declassified diplomatic reports testify more to a diplomatic and political correctness since then, from the fact that they clearly write about the discrimination that has been done to Kosovo in the Yugoslav legal and political system.

Keywords: British Diplomacy, 1981 demonstrations, Kosovo unrest, Yugoslavia.

\section{Introduction}

The UK, as one of the largest World Power, followed closely the developments of Kosovo unrest in 1981. The Embassy of the United Kingdom in Belgrade and Foreign Office in London were in constant communication, by sending reports of developments in Kosovo and Yugoslavia throughout 1981. In order to shed light to the events of 1981, research has been carried out at the British Archives on this issue. 
During the research have been found nearly 500 pages archived by the Foreign Office on riots in Yugoslavia during 1981. The documents from the British government are of particular importance as they show the authenticity of its policy at a specific time during the Cold War and high tensions between the east-socialist and capitalistWestern blocks.

The British Embassy in Belgrade will be very active during the riots in Kosovo in 1981. Mostly the embassy will gather information from its sources, process and send them to the UK Foreign Minister in the form of event descriptions, will draft analyzes by embassy officials and the Ambassador himself Mr. Bolland. During the period of April - December 1981 we will also find a lot of material compiled in the British government, such as analysis, various conclusions that hold the stamp "Secret" and "confidential". In many occasions the certain documents will be also forwarded to The British Embassy in Washington, and the same will end up at the US Administration as well as to the British NATO Delegation in Brussels.

British diplomats will report on the demonstrations in Kosovo since the $11^{\text {th }}$ of March 1981, describing them very carefully in detail and correctly by trying to always give their own version of the causes and consequences of the demonstrations. Despite the embassy's communication with the Yugoslav authorities, with the Yugoslav media and other parties, the British diplomats weren't affected by the information they receive from their sources. They are more careful and accurate about any movement that occurs.

In this research paper, the focus will be on the 20-point analytical report sent by the British Ambassador to Belgrade, Mr. Bolland, sent to the Secretary of Foreign and Commonwealth Office on 24 April 1981, which is quite substantial and detailed in the political and diplomatic fields.

\section{Brief recent history of Great Britain-Yugoslavia relations}

Shortly after the occupation of the Kingdom of Yugoslavia in April 19411', King Peter II formed the government in exile - in London. Draraza Mihailovic became Minister of War with the help of the British. Tito's partisan units operated within the territory of Yugoslavia, which created confusion in British politics as Tito was a young and unknown leader with a pro-Soviet communist orientation, while the two kingdoms had previously correct relations. ${ }^{2}$ During the Tehran Conference in November 1943, British Prime Minister Winston Churchill accepted Tito as the sole leader of the war in Yugoslavia and cut off aid to the Yugoslav king. Close cooperation between Tito and the Anglo-Americans continued until the end of World War II, until Tito strengthened ties with Stalin and established a communist political system in Yugoslavia modeled on the Soviet model. This move removed Yugoslavia from close relations with the

\footnotetext{
${ }^{1}$ Hronologija Oslobodilaçke Borbe Naroda Jugosllavije 1941-1945, Vojnoistorijski Institut, Beograd, 1964, f.31.

2 Vladimir Dedijer, Interesne Sfere, Prosveta p.d.b., f. 194.
} 
British and Americans. They now moved into open areas of conflict and went so far as to say that during the Greek civil war two American military planes crashed over Yugoslavia during 1946, while British troops in Greece were attacked by Tito-backed rebels. The port of Trieste also became a bone of contention between Tito and the Western allies who claimed control. Meanwhile the Albanians who remained under Yugoslavia were not given the right to self-determination as promised. ${ }^{1}$

Few years later Stalin, having difficulty controlling Tito, ousted him from the Comintern in 1948, more likely to pressure him to discipline and follow the Soviet political line as the communist leaders of Eastern Europe did, but this method apparently did not. turned out to be productive, as Tito immediately turned to the West and they soon responded to the request for help. In 1951 Winston Churchill, Tito's old friend, would return to power in Britain. It was the first days of the Cold War and the front lines were still kept alive, so Yugoslavia was very important to Great Britain because of its geostrategic position, from the Adriatic and Ionian Seas to the Mediterranean, and it was a wall that stopped the Soviets from reaching the hot waters.

The invitation to visit the United Kingdom was made by Secretary of State Anthony Eden in September 1952. A large part of British officials and the population openly opposed the visit of a communist leader who was a dictator and violated basic human rights. The most vocal supporter of this controversial and historic visit was the British Prime Minister Churchill, who insisted that it would be an official and not a state visit. In 1953, before the inauguration of Elizabeth II on the British throne, Tito's visit to London was organized. From the reception given to Tito in London and the very presence of his wife at Buckingham Royal Palace, it was more like a state visit than an official one. With this first visit, Tito lifted Yugoslavia out of isolation and opened the door to the west, securing Churchil's support in the event of a Soviet invasion of Yugoslavia where the West (Great Britain, USA and France) was expected to intervene alongside Yugoslavia. This was Tito's great victory from the bilateral meeting he had with Churchill on March 17, 1953 at the British government headquarters.

These interstate relations will develop correctly until the mid-1980s, when new circumstances will be created in the global political arena, namely the deep financial crisis in the Soviet bloc and the loss of the arms race, thus reducing the impact. Soviet politics in the region and in the world.

2. The demands of the demonstrators according to British diplomatic reports

According to the reports sent by the British embassy in Belgrade to the FCO in London, although at the beginning of the protests it was thought that they had a social

\footnotetext{
${ }^{1}$ Archive of R. of North Macedonia, File: National Liberation War, Box-2, File-420; Fati Iseni, Shqiptarët në Maqedonisë, Skopje, 2008. p. 131.
} 
character, but immediately the real demands appeared and their political character became clear. Mr Bolland. the Ambassador of UK at Belgrade sent a Telegram to Peter Carrington ${ }^{1}$, the Secretary of State for Foreign and Commonwealth Affairs, on 24 April 1981.

Kosovo was one of the federal units of Yugoslavia but also had the status of autonomy within Serbia. ${ }^{2}$ The first demonstrations in Kosovo began on March 11, 1981, they continued to be even more massive on March 26 and April 1, 2, 1981.

After the first demonstrations on March 11, the leadership of the University of Pristina tried to calm the students. "The next day, the rector and some of the teaching staff met the students and discussed ways of improving their living and studying conditions." ${ }^{3}$ The situation seemed to calm down but demonstrations erupted again on 26 March 1981. The student leaders met again with the rector of the University of Pristina. The student leaders began to negotiate with the rector about their rights but he broke off when they started making political demands. . The political demonstrations seem to have begun at this point, when the demonstrators pulled out ready-prepared banners and shouted hostile slogans.

The trouble was renewed in Pristina on 1 April. "The groups, each numbering 6-800 people, gathered at about $3 \mathrm{pm}$ in front of the building, where they waved banners and shouted slogans, which were being passed around on slips of paper, such as "Kosovo a Republic", "We are Albanians, not Yugoslavs", " We don't want capitalism, we want socialism", "Down with revisionism" and "We want a united Albania."4 These were the clearest political demands the students had made since the beginning of the demonstrations.

Mr. Ambassador went on to report about the riots: "The President of Kosovo's Provincial Committee speaking to an invited group of foreign journalists in Pristina on 17th April, admitted that: "All the organizers and supporters belonged to the Albanian community, that workers as well as students were among them, and that they also included some members of the League Communist. He gave revised statistics to show that only 75 civilians were injured and 8 killed, while 131 members of the security forces were injured, four seriously and one was killed, all of them Albanians. 28 people were in prison on charges for being the organizers of being the organisers of demonstrations, while 194 people were sentenced for having taken part in the

\footnotetext{
${ }^{1}$ Peter Carrington- Secretary of State for Foreign and Commonwealth Affairs - 4 May 1979 - 5 April 1982.

2 USTAV FEDERATIVNE NARODNE REPUBLIKE JUGOSLAVIJE 1946

Sluzbeni list, Beograd. 1946, p. 5.( CONSTITUTION OF THE FEDERAL PEOPLE'S REPUBLIC OF YUGOSLAVIA 1946

Official Gazette, Belgrade. 1946, p. 5.)

3 TBA, ENU 15/3 FCO28/4645 \& FCO28/4646, DS(L)1727, Departmental Series, Eastern European \& Soviet Department, KOSOVO, (Her Majesty's Ambassador at Belgrade to the Secretary of State for Foreign and Commonwealth Affairs), on 24 April 1981.

4 Ibid.
} 
demonstrations and other hostile acts." 1 This was the biggest explosion of protests in which the political demands increased but also the number of demonstrators, consequently the number of victims from both sides.

The British ambassador in Belgrade Mr. Bolland considers that Albanian nationalism is the main cause of the riots. He writes: "All the evidence suggests that the demonstrations were deliberately organized and led by politically-motivated Albanians, mainly students. The slogans and banners were clearly Albanian nationalist and irredentist in character. Other elements from left to right of the political spectrum, as various official spokesman claimed, may have been involved, but we must look to Albanian nationalism for the main cause. Indeed, a leading member of the Slovene Central Committee said recently in connection with Kosovo that "the basic causes of all Yugoslavia's serious crisis to date might be found in nationalism and not so much in social problems."2 Also he concludes that: "The Kosovo nationalists" demands have fluctuated between fusion with Albania and independence from Serbia as a Republic within Yugoslavia, though the latter might also be only a stage towards the former. ${ }^{3}$ With each outburst and subsequent changes in Province's constitutional status, Kosovo has moved a step nearer selfdetermination in Yugoslavia, but it is clear that the nationalists are still not satisfied with Serbia's nominal tutelage, although they have won equality in almost every respect with the Republics of Yugoslavia."4

\section{The Causes: The roots of unrest}

Yugoslavia was a multiethnic state, in which many ethnic communities lived. Serbs, Croats, Macedonians, Slovenes, Bosnians, Montenegrins, had a more advanced political status having their own political entity, respectively Republic within Yugoslavia. While Albanians, although according to demographic data were the third people in the Federation, but politically they were discriminated and did not have equal status with other federal units. The same is stated by Mr. Bolland: "Kosovo has erupted in violent outbursts of nationalism on several occasions since the Second World War. From the outset, the Kosovars were reluctant and to join Yugoslavia and an uprising in 1944-45 was ruthlessly suppressed, though limited resistance continued for some time afterwards. In 1955, a state of emergency was declared to

\footnotetext{
1 TBA, ENU 15/3 FC028/4645 \& FC028/4646, DS(L)1727, Departmental Series, Eastern European \& Soviet Department, KOSOVO, (Her Majesty's Ambassador at Belgrade to the Secretary of State for Foreign and Commonwealth Affairs), on 24 April 1981.

2 TBA, ENU 15/3 FC028/4645 \& FC028/4646, DS(L)1727, Departmental Series, Eastern European \& Soviet Department, KOSOVO, (Her Majesty's Ambassador at Belgrade to the Secretary of State for Foreign and Commonwealth Affairs), on 24 April 1981.

3 See also: Hajredin Hoxha, Marrëdhëniet Jogosllavo-Shqiptare, Afirmimi i Kombësisë Shqiptare në Jugosllavi\&Nacionalizmi dhe irredentizmi stalianian në Shqipëri, Rilindja, Prishtinë, 1983, p.217. 4 TBA, ENU 15/3 FCO28/4645 \& FCO28/4646, DS(L)1727, Departmental Series, Eastern European \& Soviet Department, KOSOVO, (Her Majesty's Ambassador at Belgrade to the Secretary of State for Foreign and Commonwealth Affairs), on 24 April 1981.
} 
quell disturbances apparently instigated by terrorists from Albania. Ranković and his Serb-dominated security police (UDBA) were particularly associated with the brutal suppression of the Albanian majority in Kosovo. After his downfall in 1966 and changes in UDBA, the Albanians in Kosovo and in Macedonia felt encouraged in June 1967 to demand a separate Republic within the Federation and organized large-scale demonstrations in November 1968, which were eventually put down by Armed Forces. Nationalists disturbances continued however throughout the 70s: members of the "Albanian Nationalist Liberation Movement" were imprisoned in 1975; 31 students were imprisoned in 1976 for belonging to the Movement; there were further arrests in 1979 and Tito himself visited Kosovo to calm the situation; and in 1980, eight of those previously arrested were sentenced to terms of imprisonment of three to eight years." ${ }^{1}$ The dire situation in Kosovo would return after 1987.2 The suppression of Kosovo Autonomy in March 1989, with the change of some constitutional amendments, returned Kosovo from status as a constituent part of Federation in that of Autonomy within Serbia only. ${ }^{3}$ Poisoning of Albanian students in high schools, were increasing daily in the period March-April 1990.4

"It seems likely that these political causes were accentuated by economic and social grievances. Despite the considerable efforts to develop Kosovo with aid from the Federal Fund for the under-develop regions and more recently with direct investment by the Republics and individual enterprises, the Province still lags far behind in every respect apart from its phenomenal birth rate! Prospects for employment have not kept pace with the aspirations of the excessively large number of young people leaving school and university, who, have been educated mainly in Albanian, do not have the same mobility to find work elsewhere in Yugoslavia. Thus, the population jumped from 733000 in 1948 to 1,566,000 in 1979 of whom 382,000 were at school and 47,497 at university, while only 168,000 were employed in social sector. The lack of work has not prevented people, mainly poorly educated peasants, from flooding into Pristina and other towns, which are bursting at the seams and hardly able to cope with the enormous social problems. Another factor, which is coming to light, was the failure of the local leadership to listen to warnings about growing discontent amongst the students and, certainly after the first outburst on 11 March, to take adequate remedial measures. My German colleague has told me that the senior Party Leaders spoke about this to Mr Willy Brandt during a recent visit to Belgrade, implying that,

\footnotetext{
1 Ibid.

2Marc Weller, Contested Statehood, Kosovo's Struggle for Independence, Oxford University Press, 2009, p.37.

3 Jasminka Udoviçki \& James Ridgeway, Makthi Etnik I Jugosllavisë, Albin, Tiranë, 1998, p. 60.

${ }^{4}$ Noel Malcolm, Kosovo a short history, Papermac, London, 1998, p.345.
} 
Bakali himself, the Communist League President in Kosovo, was ill-informed and complacent."

\section{The opinion of Mr. Bolland for the status of Kosovo}

The British Ambassador to Belgrade, Mr. Bolland, based on the knowledge and information gathered by the embassy service, has a clear concept of the Kosovo issue and its legal and political status within the federation. He recommends: "By any logical criteria, Kosovo, within its present borders, ought to have equal status in Yugoslavia with the Republics of Montenegro, Slovenia and Macedonia, since its population is as large and as ethnically homogeneous as any of them. But the Yugoslav leadership has resolutely refused to yield to such logic for internal political and security reasons. Immediately after the War, the Party did not want to antagonize the Serbs further by hiving off Kosovo, since the latter had already "lost" Macedonia and Bosnia and Herzegovina from pre-War Greater Serbia. Kosovo, as the heart of the medieval Serbian kingdom destroyed by the Turks in 1389, was then, as now, capable of stirring up intense feelings among Serbs. Moreover, after 1948 Albania was a hostile country and Yugoslavia could not risk a separate Albanian Republic in Kosovo which might become disaffected. Having adopted such a policy, the Party has been obliged to prosecute it uncompromisingly ever since, because to change it now would be to open a Pandora's box of requests: first, from the significant Albanian communities in Macedonia and in Montenegro to join the Kosovo Republic; then from the Autonomous Province of Vojvodina for parity, which would upset the Serbs both there and in Serbia proper; and, finally for readjustments of the other Republican borders to take account in of minorities' wishes. As Dolanc, a member of the Party Presidium, put it: "The creation of a Republic would mean absolutely certainly an attack on the integrity of Yugoslavia". And the Party Secretary, Dragosavac, said unequivocally: "The question of Kosovo is resolved, it is an integral part of Serbia and the Yugoslav Federation."2

"Thus, it would seem we are witnessing, once again, the classic situation of the irresistible force of nationalism meeting the immovable object of official policy. Something, somewhere has to give: Yugoslavia's problem is to decide what. In the past, it has succeeded after each outburst of nationalism in Kosovo in calming the situation by offering constitutional concessions which cumulatively have given Kosovo virtually Republican status. ${ }^{3}$ It is difficult to see -as senior Party leaders themselves admit privately how much further they can go short of granting total

\footnotetext{
1 TBA, ENU 15/3 FC028/4645 \& FCO28/4646, DS(L)1727, Departmental Series, Eastern European \& Soviet Department, KOSOVO, (Her Majesty's Ambassador at Belgrade to the Secretary of State for Foreign and Commonwealth Affairs), on 24 April 1981.

2 Ibid.

${ }^{3}$ Sabrina P. Ramet, Balkan Babel, Westview, 2002, USA, p. 56.
} 
Republican itself. But I have no doubt that Yugoslavia's ingenious constitutional experts will be re-examining the problem." 1

5. Foreign interference possibility on Yugoslavia during 1981

After the riots broke out in the province of Kosovo in Yugoslavia, suspicions arose as to who had instigated them. The communist leader Yugoslavia raised suspicions in two directions: Soviet involvement or from the People's Republic of Albania.

Why the suspicion of Soviet intervention? Yugoslavia since 1948 broke off relations with the Soviet Union and throughout the Cold War period cooperated with the West, respectively with the US, Great Britain and Western Europe as a whole. UK interest was Yugoslavia to remain stable as it was the west "protected" area from any Soviet Union threat. ${ }^{2}$

Perhaps the Soviets had an interest in creating turbulent waters in this part of the Balkans so that they could then maneuver more easily. But the British diplomatic service in Belgrade clearly concludes that the protests were not instigated by the Soviet Union, which from this time frame liberates the Albanian Movement and the students of that time from being suspected of having anything to do with the former.

Mr Bolland will write to Secretary of State of FCO: "The events also have an international dimension. I have no evidence of Soviet Involvement and Crličkov, a member of Presidium of the League of Communists, expressly ruled it out in a conversation with me on 6 April. Albanian involvement, though denied officially in Tirana and not admitted openly in Belgrade, is possible."3

Unlike the Soviet Union, the suspicions of any eventual intervention by the Albanian State were more convincing. The reasons were numerous, despite the attempt to normalize relations in the cultural and economic field, they were still in relation to the wolf and the fox. As the British ambassador will state: "Certainly, the temptation to meddle must be strong, when across the border live half as many ethnic Albanians as in Albania itself. And Tirana made it clear in a strongly worded article "Zëri i popullit" on 8 April, much to Yugoslavia's embarrassment, that Albania had the same right as Yugoslavia or any other country to defend its national minorities. Moreover, the Albanian Ambassador here makes no secret or his country's dissatisfaction with the present borders with Yugoslavia. But as various Yugoslav leaders have pointed out in

\footnotetext{
1 TBA, ENU 15/3 FCO28/4645 \& FCO28/4646, DS(L)1727, Departmental Series, Eastern European \& Soviet Department, KOSOVO, (Her Majesty's Ambassador at Belgrade to the Secretary of State for Foreign and Commonwealth Affairs), on 24 April 1981.

2 FO 371/102179 Eden note to Churchill, 14 July 1952; PREM 11/578 FO report to Churchill, March 1953; PREM 11/578 Wellington letter to Colville, 17 Feb 1953; FO 371/102184 Eden minute, Belgrade telegram to FO, 1 December 1952; PREM 11/577 Report on meeting at 10 Downing Street, 17 March 1953.

3 TBA, ENU 15/3 FCO28/4645 \& FCO28/4646, DS(L)1727, Departmental Series, Eastern European \& Soviet Department, KOSOVO, (Her Majesty's Ambassador at Belgrade to the Secretary of State for Foreign and Commonwealth Affairs), on 24 April 1981.
} 
renewed critical exchanges with Tirana, stability in Kosovo is just as much in Albanian's interest much as in Yugoslavia's. They might have added that this applied particularly as Enver Hoxha approaches the end of his reign, when a struggle for power could develop. Indeed, there is much speculation that among the demonstrators were elements who had latter situation in mind as a motive for agitating now.

Externally, the main political consequence was the deterioration in Yugoslavia's relations with Albania after a steady improvement over the last two years. The Yugoslav Leadership were careful in their public statements to avoid implicating Albania. This attitude changed the following leader in "Zëri I Popullit " of 8 April, which was immediately condemned as interference in Yugoslavia's internal affairs for offering support to the nationalists and inciting them to open rebellion." 1

\section{The consequences}

The riots of March and April 1981 had serious consequences for the political, security and economic systems. These riots in Kosovo highlighted many discriminations against Kosovo in many dimensions. As the Ambassador will write: "Although it will probably take some time for the internal political consequences to emerge. It is therefore already likely that there were will be changes in Kosovo leadership for their poor handling of the events. It is clearly accepted by the Party Leadership that the causes lay not in the external threat, but "in our own weaknesses, the insufficiently developed socialist self-management system. "The communist League and other socio-political organizations are analysing how it was possible for them to have been taken by surprise and to have miscalculated the first indications of a political trouble. But, whatever the results of these enquirers, the inescapable conclusion is that once again the Kosovo leadership have shown their inability to resolve the old dilemma of representing the national aspirations of their Province while adhering to the Party line which admits of no basic change in Kosovo's status."

The press was an issue that appropriate measures were taken in relation to the situation. Mr. Bolland will emphasize: "Meanwhile, another part of the Communist League's apparatus is examining the faults which the events revealed in the system of public information. The press, led by some caustic leaders in "Politika", its full of criticism about the delays in providing information on what really happened. Although by the press standards of other communist countries the events have been remarkably well documented the Kosovo, and indeed the central authorities, were at first very reluctant to tell anything like the whole story. In the meantime, the authorities have been grappling with the immediate problems of restoring the situation. A start has been made on improving conditions for students at Pristina University and other short-term measures have been introduced such as reducing the

\footnotetext{
1 TBA, ENU 15/3 FCO28/4645 \& FCO28/4646, DS(L)1727, Departmental Series, Eastern European \& Soviet Department, KOSOVO, (Her Majesty's Ambassador at Belgrade to the Secretary of State for Foreign and Commonwealth Affairs), on 24 April 1981.
} 
price of certain basic foodstuffs. Political leaders are now concentrating on long-term measures, Communist League members have been firmly called to order and the other social and political organizations are taking action to reassert the official line.

During the next 5 years Kosovo will receive about 20 billion pounds for the development of the economy and social services from the Federal Fund, where its share has been increased from 30-43\%". Under the new 5-year plan Kosovo will also receive other funds on a greater scale than ever before which will enable a big expansion in education, culture and public health, the erection of 40.000 new flats and the construction of or expansion of industrial plants, particularly to exploit Kosovo's mineral wealth and energy resources, thus providing more jobs and growth rate $60 \%$ above the Yugoslav average." 1

\section{Conclusion}

Based on the analysis of British diplomatic documents which have been declassified in recent years, we see that the British government was deeply interested in the riots in Kosovo (Yugoslavia), and that the telegrams sent clearly show that the diplomats had all the information as before the riots. as well as during riots.

British diplomacy considers that the riots of students and the population in Kosovo in 1981 had political motives. The Yugoslav leader and the LCJ were found by surprise and created political turmoil within the political hierarchy itself in the federation and the province of Kosovo itself by dismissing and reappointing new figures in the party and state leadership.

Mr. Bolland will conclude: "The events in Kosovo came as a rude awakening to the Yugoslav leadership as it completed its first year without Tito. They revealed, however, not a new but rather an endemic problem which, with all his authority and charism, even Tito had not been able to solve. Nor, as they accept, can the present leaders. But they did show on this occasion, after their initial surprise, a welcome maturity in the restrained and positive way in which they handled the situation. With a minimum use of force, they quickly brought the disorders under control and prevented them from involving the people of Kosovo at large. This attitude together with their refusal to accept calls for the use of the "firm hand" and instead to continue along their chosen path towards greater democratisation provide reasonable grounds for believing that the leadership will be able to keep the Federation together."2

British diplomacy considered that there was no Soviet intervention, riots came from within the students and Albanians in Kosovo and Yugoslavia were discriminated

\footnotetext{
1 TBA, ENU 15/3 FCO28/4645 \& FCO28/4646, DS(L)1727, Departmental Series, Eastern European \& Soviet Department, KOSOVO, (Her Majesty's Ambassador at Belgrade to the Secretary of State for Foreign and Commonwealth Affairs), on 24 April 1981.

2 Peter Carrington- Secretary of State for Foreign and Commonwealth Affairs - 4 May 1979 - 5 April 1982.
} 
against. But they conceived that Nationalism in Kosovo was an endemic problem which not even Tito could solve it.

\section{References}

[1] Archive of R. of North Macedonia, File: National Liberation War, Box-2, File420

[2] Dedijer, Vladimir, Interesne Sfere, Prosveta, 1950

[3] TBA (The British Archives), ENU 15/3 FC028/4645 \& FC028/4646, DS(L)1727, Departmental Series, Eastern European \& Soviet Department, KOSOVO, (Her Majesty's Ambassador at Belgrade to the Secretary of State for Foreign and Commonwealth Affairs), on 24 April 1981.

[4] Iseni, Fati, Shqiptarët në Maqedoni, Shkup, 2008. F. 131.

[5] Hoxha, Hajredin, Marrëdhëniet Jogosllavo-Shqiptare, Afirmimi i Kombësisë Shqiptare në Jugosllavi\&Nacionalizmi dhe irredentizmi stalianian në Shqipëri, Rilindja, Prishtinë, 1983.

[6] Hronologija Oslobodilaçke Borbe Naroda Jugosllavije 1941-1945, Vojnoistorijski Institut, Beograd, 1964.

[7] Malcolm, Noel, Kosovo a short history, Papermac, London, 1998.

[8] Ramet, P Sabrina. Balkan Babel, Westview, 2002, USA.

[9] Udoviçki, Jasminka \& Ridgeway James, Makthi Etnik i Jugosllavisë, Albin, Tiranë, 1998.

[10] Ustav Federativne Narodne Republike Jugoslavije (Constitution of the Peopels Federal Republic of Jugoslavia)1946, Sluzbeni list, Beograd. 1946.

[11] Weller, Marc, Contested Statehood, Kosovo's Struggle for Independence, Oxford University Press, 2009. 